\title{
Debt, Marketing Communication, and The City: Designed Social Control ${ }^{\star}$
}

\begin{abstract}
This paper theorizes debt and communication marketing as social control instruments. It is argued that these elements reinforce and support each other and work together to govern and design us through 'psychopower'. Together, they create a new type of worker, abuse the idea of freedom, and destroy attention. The 2011/12 Occupy Wall Street protests that emerged all over the world proved the importance of the city as a political public space. Although research shows that energy is generated in the digital, virtual, and networked space, and physical space is still crucial to challenge dominant power relations. However, debt and marketing-based communication start power up simultaneously both on the physical and the digital levels. The question is, how can this specific dynamic be challenged?
\end{abstract}

\author{
Oliver Vodeb. \\ Swinburne University of Tech- \\ nology. \\ Researcher, Lecturer Communi- \\ cation Design. \\ Melbourne, Australia. \\ Correo electrónico: \\ oliver@memefest.org
}

Recibido: Julio 2014

Aprobado: Abril 2015

Key words:

Debt, design, marketing communication, networks, care, socially responsive communication, the city, dialogue. 


\section{Deuda, marketing y comunicación, y la ciudad: diseñan- do el control social}

\section{Resumen}

En este trabajo se teoriza la deuda y la comercialización de comunicación como instrumentos de control social. Se argumenta que estos elementos se refuerzan y se apoyan mutuamente, trabajan juntos para gobernar y nos diseñan a través de "psychopower '. Juntos, crean un nuevo tipo de trabajador, abusan de la idea de libertad y destruyen la atención. La 2011/12 Occupy Wall Street protestas que surgieron en todo el mundo demostró la importancia de la ciudad como espacio público político. Aunque la investigación muestra que la energía se genera en el espacio digital, virtual y en red, el espacio físico sigue siendo decisivo para impugnar las relaciones de poder dominantes. Sin embargo, la deuda y el trabajo de comunicación basada en el marketing, pone en marcha el poder de forma simultánea tanto en el físico como en los escenarios digitales. La pregunta es, ¿cómo podemos impugnar esta dinámica específica?
Palabras clave:

Deuda, diseño, marketing y

comunicación, las redes, la atención, la comunicación socialmente responsivo, la ciudad, el diálogo. 


\section{The City}

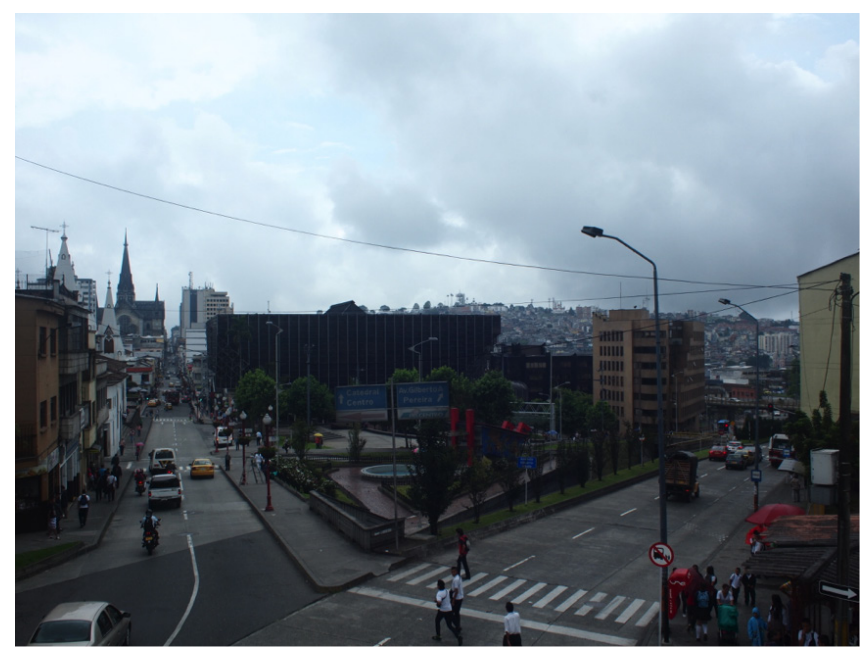

Figure 1. Manizales, Colombia, April 2013. Photo: Oliver Vodeb.

Increasingly, the city has become people's primary habitat. Its economic power creates flows of millions of rural inhabitants who move to the city, while its cultural nature creates an environment that seems to fulfil the most passionate of human desires. It shapes our social ties and lifestyles, our relationship to nature, technologies, and our desired aesthetic values (Harvey, 2008). In this light, it is also the medium for the capitalist accumulation of power.

Habermas (1989) sees the city as a vital centre of the public sphere. True political activities -action and speaking- cannot take place without the presence of others, i.e., without the public, and without the city and its public spaces. 
The city plays a significant role in social change; in relation to debt, the city has become a crucial medium, through which capital is invested in real estate under the conditions of the ruling class. An interesting relation can be seen between the city and the profit dynamics of the debt industry. As seen in most cities, it is the low-income-earning, mostly precarious -temporary employed, contract-based workers along with the creative workers, artists and designers -the 'cognitariat'who cause with their daily activities the real-estate market to rise. However, the physical representation of these classes, and the movement of their bodies, is strictly regulated and channelled so that they do not interfere with the mechanisms of capitalisation that the city carefully implements under the rule of those in power. Workers work in the city, contribute to the daily economy and than move out to other areas, where they live. Creative workers stay in cool gentrified suburbs, moving elsewhere when rents are getting to high as they have made the area cool enough for richer people to move in.

Through its strategies of urbanisation, the city channels the regimes of capitalisation into its centres. Meanwhile, in the suburbs, the social and political dimensions of urbanisation are intriguing. Suburbs are being made through private debt, and a fascinating dimension of social control is involved in this. It is a fact that indebted homeowners typically don't go on strike. It is also a fact that the biggest debt-related profits are being made through the poorest people who don't live in the urban centres or gentrified suburbs.

Urbanisation strategies are intertwined with macro-economic strategies and corporate business strategies. Capital needs to control urbanisation, since urbanisation is the result of class power in action (Harvey, 2008).

David Harvey convincingly argues that the right to the city "is a right to change ourselves by changing the city". It is "moreover, a common rather than an individual 
right since this transformation inevitably depends upon the exercise of a collective power to reshape the processes of urbanization" (Harvey, 2008).

The Occupy Wall Street movement, which started in late 2011 in New York and spread throughout the globe, revealed the power of the city. The movement protested against the growing power of the ruling 1percent and the rule of money over life. In essence, the movement's message is "we want to be heard". For years, activists, intellectuals, and engaged citizens have been expressing their outrage against the growing powers of the corrupt financial capitalist system via the Internet and the media. But until a physical occupation took place in the heart of the world's financial centre, such critique was tolerated. As the movement has spread, more and more cities have seen occupations, which introduced a particular horizontal dynamic of communication -a true public sphere, a genuine dialogue, and engaged participation. Debt was one of the main themes under discussion, with the movement bringing this urgent issue to the streets, into the media, into the realm of public consciousness, into schools, universities, professional locations, homes, and intimate discussions and relationships. The importance of debt for the Occupy Wall Street movement is exemplified by the fact that anarchist anthropologist David Graeber's book Debt (2012) became the movement's manifesto. After a bit less than two months of the movement's global public presence, the New York police finally cleaned up the occupied Zuccotti Park with brute force, and other cities followed suit.

The occupation started as a response to an email sent out by the Canadian organisation Adbusters, which is known for its critique of advertising and the broader media industry. "Occupy Wall Street, bring tent", it said. The right to transform the city, the right to change ourselves was executed and the city, with its streets, buildings, and trees, made the digital protest so much more powerful. 


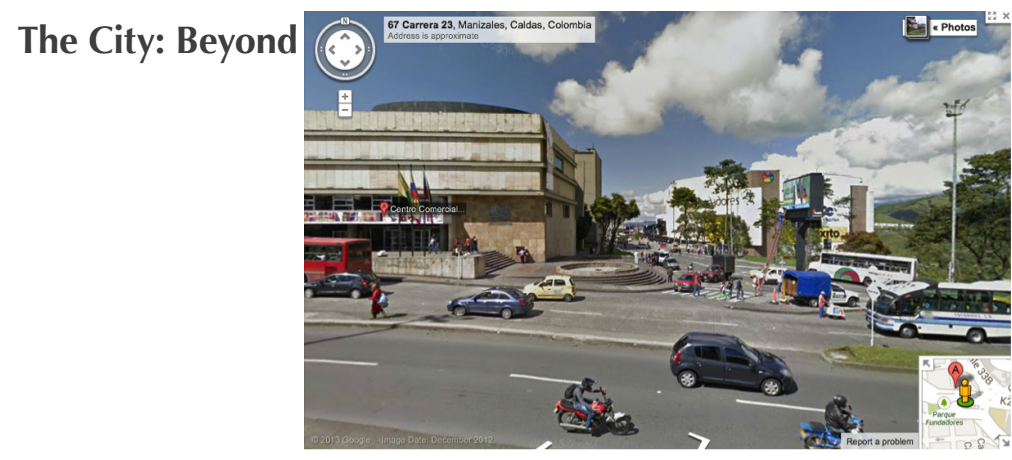

Figure 2. Manizales. Source: Google Street view.

Soon after Occupy Wall Street started, Dutch media theorist Geert Lovink and Italian philosopher Franco 'Bifo' Berardi published "A Call to the Army of Love and to the Army of Software" (2011). A manifesto-like text, it argued that the protests and occupations would not change anything:

\footnotetext{
Resistance will not resist, and our fight will not stop the legal crimes. Let's be frank, we will not persuade our enemies to end their predatory attacks ("let's make even more profit from the next downfall") for the simple reason that our enemies are not human beings. They are machines. [...] Bankers and investors are not the real decision-makers, they are participants in an economy of gestural confusion. The real process of predatory power has become automated. The transfer of resources and wealth from those who produce to those who do nothing except oversee the abstract patterns of financial transactions is embedded in the machine, in the software that governs the machine.
}

Protests are short-term interventions while occupations are here to stay. Once occupations start to spread in the physical city, they become a serious threat to dominant powers. The virtualisation of human relationships has co-created an 
extreme level of individualism, now even more easily exploited by machines, software, and algorithms.

With the rise of the so-called 'network society', spatial relations have changed and have become mediated, virtualised, and organised into networks and digital experiences -into what Manuel Castells labels "the informational city". Castells observes that "[...] people still live in places. But because function and power in our societies are organized in the space of flows (the digital, networked and mediated space), the structural domination of its logic essentially alters the meaning and dynamics of places" (Castells, 2000, p. 174). Physical and digital experiences are disconnected; the space of 'flows' and the space of place are separate entities, with power mainly organised in the space of flows, as Castell argues. As this trend continues, social experiences become further disconnected thus creating significant problems in constructing sustainable communities.

From the creative city concepts and manifestations of gentrification to advertising's natural tendency to use the public cityscape as a private billboard, physical space is transformed into a commercial interface. The digital use of physical space paired with mobile technologies uses the city as a commercial amusement park. Physical waiting rooms become opportunities to log in, connect, and become part of the virtual machine. The physical experience is increasingly shaped by digital commercial preferences. Still, the city as a public space remains powerful in its potentials. The processes of marketing colonisation, debt, and privatisation in the city seem unstoppable. The question is, can we use the power of the space of flows and the potentials of the space of place to connect them in a different way?

\section{Marketing Communication and Debt: Designed Social Control}

Returning to the topic of debt, capitalist domination does not derive only from "buying power" but from the possibilities of reconfiguring relations of domination 
and subjectification (Lazzarato, 2012, p. 93). In order to think about possible interventions that would bridge the space of flows and space of place, we need to consider two things: a) the new type of worker; b) the new type of marketing-based communication.

Italian philosopher Maurizio Lazzarato offers a compelling and useful analysis in his book The Making of the Indebted Man (2012); he writes about conditions where the 'laws' of market competition are extended to all areas of social life. Health and education, for example, become investments made by the individual in their individual capital. The worker is no longer only labour power; they are reconceived as personal capital, making business choices through good or bad 'investment' decisions as they move from one professional position to another. These strategies increase or decrease their capital value. This reconceptualisation of the individual as an "entrepreneur-of-the-self" teaches us about a significant shift in the nature of governance of capitalism (Lazzarato 2012).

- $\quad$ submission through a specific authority, which is paradoxically linked to freedom, coming;

- through destruction of attention and therefore destruction of care.

In The Indebted Man, Lazzarato is interested in particular subjectivities the "indebted man" develops. He links these subjectivities to the associated right to evaluation, moralisation, and temporalities. Debt is a moral burden a moral obligation that is socially and culturally reinforced even if most of the debt is not legitimate in the first place. The indebted subject is associated with two kinds of work; salaried labour and work upon the self (i.e., he is working on himself - making changes in his life, etc.). This work is needed to produce a subject that is willing to give promises and to repay the debt. This subject must also be ready to assume their guilt for being an indebted subject. Moreover, a specific set of temporalities is produced with indebtedness. The indebted man/woman must be able to repay (to remember one's 
promise). In this process, one has to make one's behaviour predictable, structured, regular, and calculating. Lazzarato argues that such temporalities directly negatively influence future resistance, as there has to be a reproduction of a situation where one reinforces one's own capacity to repay. Because the indebted man/woman is an entrepreneur-of-the-self, all social networks and situations, private or public, are here to be used for the entrepreneurial life project.

French social psychologist Jean Leon Beauvois's (Beauvois 2000) analysis of several social-psychological experiments demonstrated that an individual, when put into a certain situation and addressed by authority, will submit to this authority and do what they are asked to do. Beauvois discovered that an individual who has been granted freedom will normally rationalize their subordination and change their beliefs.

This relates to the logic of submission. Debt, especially in the early stage, is strongly associated with freedom as it gives an individual the opportunity to deal with capital that enhances their living standard and options. More importantly, it is associated with freedom as it enables the individual to take part in the consumerist race, which is highly supported by the audio-visual industries that itself is grounded on the notion of freedom -freedom to consume, freedom to buy, freedom to conform, freedom to submit, and freedom to design one's individual brand as the entrepreneur-of-the-self with the freedom to be creative while doing it. The moral obligation to repay debt, the self-disciplining mode of the indebted entrepreneurof-the-self, therefore, becomes value.

Attention is another important dimension related to this dynamic. Marketing-based communication works within the political economy of attention. Over the decades, the audio-visual industries have learned how to capture our attention in order to capitalise on it. From the perspective of advertising, attention equals capital and profit; from a social and personal perspective, attention is related to care. 
French philosopher Bernard Steigler showed that destruction of attention through cultural industries is directly related to the destruction of care. Stiegler extends on Michel Foucault's concept of 'biopower' by proposing his concept of 'psychopower' as the next stage of governance. While 'biopower' is a form of care imposed by the state -even for disciplinary purposes- the new governance of 'psychopower' is based on a state of care-less-ness that controls hegemonically through psychotechnologies (Stiegler, 2012). The purpose of this power is to control and produce consumers (Stiegler, 2012, p. 42).

The objective of these operations is to gain control over social networks, that is, the digital networks where new models for the capture and formation of psychic attention as well as collective attention are revealed. This process constitutes a new stage of what Steigler (2012) describes as a process of grammatization. Through this process, individuation becomes formalised, and reproducible. Therefore, it becomes calculable and automatable:

\footnotetext{
The gigantic financial crisis sending tremors all over the world is the disastrous result of the hegemony of the short term of which the destruction of attention is at once effect and cause. ... marketing, from the emergence of the programme industries, transforms the psychotechniques of the self and of psychic individuation into industrial psychotechnologies of transindividuation, that is, into psychotechnologies threaded by networks. (Stiegler \& Rogoff, 2010)
}

Through the process of grammatization, these digital networks systematise, calculate, and organise data in order to find new ways of surveillance, predict behavior patterns, and over see capitalisation. These digital networks, such as Facebook, capture attention and channel it in a way that destroys attention.

The ways of capturing and formatting psychic attention are inherently related with the social situation of the precarious (digital) labourer. The user's attention is formatted to work towards self-promotion. This again on the second level is formatted to 
generate direct financial profit for the network technology owner. The social relation is formatted to act reciprocal in the sense of automating this business transaction.

To conclude this section, social relations are shaped according to the instruments that control them. Debt and marketing-based communication work in the realm of care-less-ness. The level of abstraction with the underlying ideology of profit tied to the actions of the entrepreneur-of-the-self imposed on social relations destroys care. This has broader social implications because it works towards un-sustainment of the economy, ecology, and society, but also because it affects our capability to critically act, think, and relate to the world in an engaged way.

\title{
The City, Cultural Sustainment and Socially Responsive Interspatial Counter Practice
}

\author{
"The only real form of deep attention is dialogue"
}

(Plato)

Key parts of cultural sustainment are relations between communities and distributed economies that enhance viable social ecologies. By 'distributed economies', I mean economies of collaboration, sharing, participation and bottom-up innovation. Power relations in distributed economies work within cognitive capitalism's logic only to a certain extent. Information and communication technologies, knowledge, and innovation are highly important. However, valorisation happens differently and under the logic of the commons, which means that any capital produced should be accessible to the wider society.

Distributed economies include peer-to-peer, open source, gift economies, and crowd-driven (crowd sourcing, crowd funding) economies. Distributed economies are mainly based on the logic of: a) decentralised power; b) the notion that sharing benefits the person who shares as well as the broader community; c) collective self-governance; and in many cases, d) a common/shared property (Bauwens, 2005, 
2006; Johansson, Kisch \& Mirata, 2005). This logic fundamentally shifts the precarious position of the worker and it creates an ethic that works in opposition to the enforced individualism of the entrepreneur-of-the-self that is enforced through debt.

Urban space is fundamentally connected with local economies. We should examine the relation between communities, the relation of 'space of place' versus the 'space of flows', and how it can be mediated through communication that does not work on the same principles as marketing-based communication.

An important step towards empowering communities of sustainment and countering the coordinated effects of debt and marketing-based communication is that the approach to communication and representation does not deploy only the symbolic image of the community but is focused on its operative dimension. It is about the visualisation of citizenship (Cruz, 2012). Things become visible not mainly through the image but through communicative inter-action and response-ability.

At the level of institutions of representation, I am referring to socially responsive communication and art. Crucially, this type of communication and art create different power relations - more evenly distributed-than marketing-based communication as they fundamentally question the dominance of instrumental marketing and social marketing, but at the same time does not completely exclude commercial value creation. These approaches create dialogue and/or conditions for dialogue in a public sphere that is colonised by instrumental commercial communication (Vodeb, 2008, Vodeb, Janovic, 2011).

Socially responsive communication works mostly on the level of conflict, as conditions for dialogue generally do not exist. For example, the dynamic created by debt together with marketing-based communication is highly anti-dialogic and hierarchical. Communicative conflict opens space and makes the invisible visible. Socially responsive communication distributes power and as such is a counter- 
practice. It can be, as in the case of Occupy Wall Street, be used for amorphous movements (Lichty, 2013), as well as non-institutionalised initiatives and institutions (commercial and non-commercial) that work towards a culture of sustainment.

Instead of a debt-driven economy fuelled by cognitive capitalism's excess of antidialogic marketing communication, distributed economies have to be driven by dialogue and collaborative communities. The connection between the digital and physical that works on the symbolic level, but also integrates structural politics, is crucial in order to establish an communication/social ecology of cultural sustainment. A coordinated relationship between socially responsive interspatial communication and art and distributed economies that bridge the 'space of pla$\mathrm{ce}^{\prime}$ and 'space of flows' in the city is key to fight the predatory logic of debt and marketing-based communication.

\section{References}

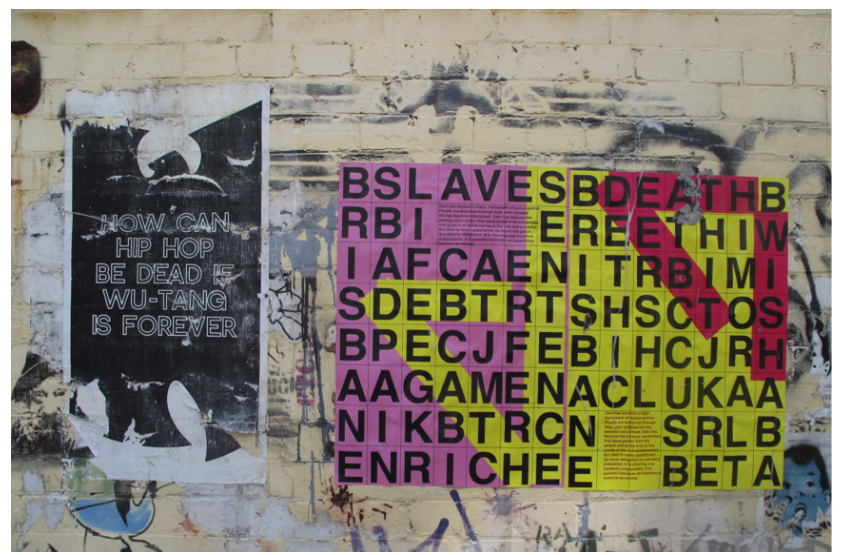

Figure 3. Memefest poster campaign against debt, Brisbane 2012. Photo: Oliver Vodeb. 
Bauwens, M. (2005). The Political Economy of Peer Production. Kroker A. \& M. (Eds.). Retrieved from http://www.ctheory.net/articles.aspx?id=499

. (2006). The Political Economy of Peer Production. Post-autistic economics review, 37, 33-44. Retrieved from http://www.paecon.net/PAEReview/issue37/ Bauwens37.htm

Beauvois, J., L. (2000). The Treatise on Liberal Slavery: Analysis of Subordination Krt, Ljubljana

Castells, M. (2000). The Rise of the Network Society. The Information Age: Economy, Society, and Culture Volume I (Information Age Series). Malden: Blackwell.

Cruz, T. (2012). Mapping Non-Conformity: Post-Bubble Urban Strategies. In: Mirzzoef, N. (Ed.), Visual Culture Reader. Third ed. Routledge.

Graeber, D. (2012). Debt: The First 5000 Years. Melville House.

Habermas, J. (1989). The Structural Transformation of the Public Sphere. Cambridge: MIT Press.

Harvey, D. (2008). The Right to the City. New Left Review, 53. Retrieved from http:// newleftreview.org/II/53/david-harvey-the-right-to-the-city

Johansson, A., Kisch, P., \& Mirata, M. (2005). Distributed economies - A new engine for innovation. Journal of Cleaner Production, 13(10-11), 971-9. Elsevier.

Lazzarato, M. (2012). The Making of the Indebted Man: An Essay on the Neoliberal 
Condition. Semiotext(e).

Lichty, P. (2013). Variant Analyses: Interrogations of New Media Art and Culture. Institute for Network Cultures.

Lovink, G., \& Berardi, F. (2011). A Call to the Army of Love and to the Army of Software. Retrieved from http://interactivist.autonomedia.org/node/32852

Stiegler, B. (2012). Care. In: Cohen, T. (Ed.), Telemorphosis. Theory in the Era of Climate Change. Open Humanities Press.

Stiegler, B., \& Rogoff, I. (2010). Transindividuation. Retrieved from http://www.eflux.com/journal/transindividuation/

Vodeb, O. (2008). Socially Responsive Communication. Ljubljana: Faculty for Social Sciences.

Vodeb, O., \& Janović, N. (2011). Demonstrating Relevance: Response-Ability. Theory, practice and Imagination of Socially Responsive Communication. Ljubljana: Fakulteta za družbene vede.

Cómo citar este artículo:

Vodeb, O. (2015). Debt, Marketing Communication, and The City: Designed Social Control. Revista Kepes, 11, 193-207. 